\title{
Acknowledgments
}

AMONG THE MANY PEOPLE to whom I am grateful for help with this biography-contemplated but postponed for so long - a few must be mentioned.

Without the encouragement of Dr. Gerald Langford and Dr. Harry Ransom, the book in this form might never have been started. Without the aid of my mother, my aunts, Mrs. Frank Anderson and Mrs. Leland Barbee, my uncle, Mr. Ben Clayton, and Mrs. Helen Ainsworth, Mr. Hu Harris, Mr. Lamar Fleming, Jr., Mr. Ernest Jones, Mr. Winthrop Brown, Mr. George C. McGhee, and Mr. Jean Monnet, the study would have lacked important information. Without the help of Mrs. Frances Debogory Horton, the manuscript might not have been finished on time.

In Tupelo, Mississippi, and Jackson, Tennessee, Clayton and Burdine relatives, as well as childhood friends of my father's, were gracious and generous to me in my search for material on the early days. Among those to whom I talked were Mr. John Anderson, Mr. and Mrs. Stewart Clayton, Mr. John Richey Clayton, Mr. Cacye Wax, Mr. Harris Brown, Mr. Curtis Bray, Miss Anna Butler, Mrs. Will Weis, Mrs. Will Holland, Miss Mary Timberlake, Mr. and Mrs. Seale Johnson, Mrs. T. A. Andrews, Mrs. Lotta Short, and Mr. Hugh Ross. Mr. Walter Chandler of Memphis was kind enough to send me his "Personal Recollections of Jackson." 
viii

As these pages go to press, international affairs move into ever more disturbing crises-situations where Will Clayton's thinking seems as prophetic as in the emergencies herein portrayed. For his views on how to cope with new threats to peace, a later and more expansive biography will be needed.

Ellen Clayton Garwood

\section{A Note to the Reader}

In a biography short enough to serve as a book supplement in The Texas Quarterly it was impossible to cover all Will Clayton's activities or to include all the important events of the times. A chronological table, supplying more fully both background and foreground detail, has been added to the biography here. It is hoped that this "Chronology" will serve the reader as a useful guide through the maze of principal world events which have paralleled or nearly coincided with the main events in Will Clayton's life. 